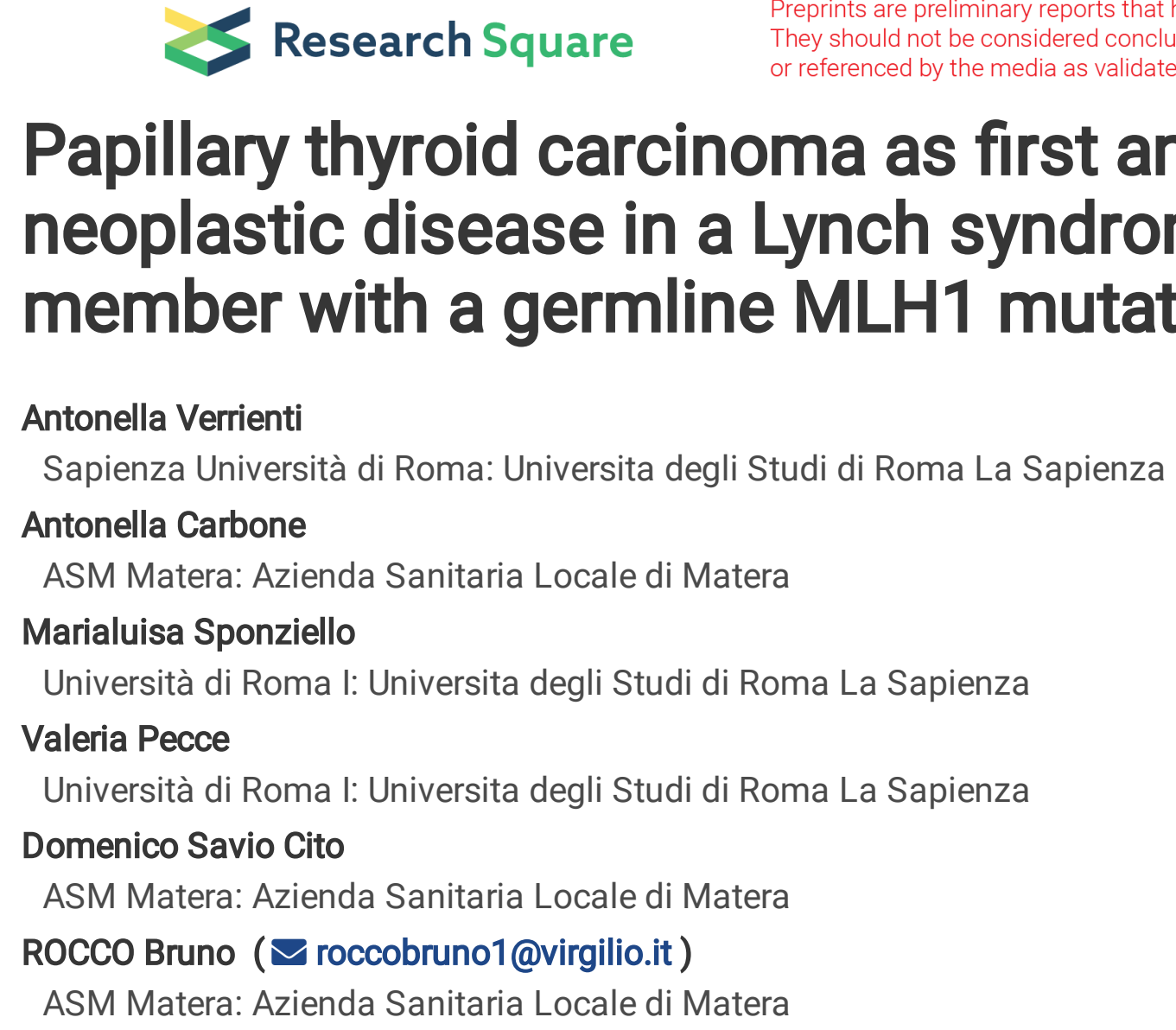

\section{Antonella Verrienti}

Sapienza Università di Roma: Universita degli Studi di Roma La Sapienza

\section{Antonella Carbone}

ASM Matera: Azienda Sanitaria Locale di Matera

\section{Marialuisa Sponziello}

Università di Roma I: Universita degli Studi di Roma La Sapienza

\section{Valeria Pecce}

Università di Roma I: Universita degli Studi di Roma La Sapienza

\section{Domenico Savio Cito}

ASM Matera: Azienda Sanitaria Locale di Matera

ROCCO Bruno ( $\square$ roccobruno1@virgilio.it)

ASM Matera: Azienda Sanitaria Locale di Matera

\title{
Papillary thyroid carcinoma as first and isolated neoplastic disease in a Lynch syndrome family member with a germline MLH1 mutation
}

\section{Research Article}

Keywords:

Posted Date: February 18th, 2022

DOl: https://doi.org/10.21203/rs.3.rs-1359534/v1

License: (a) (i) This work is licensed under a Creative Commons Attribution 4.0 International License. Read Full License

Version of Record: A version of this preprint was published at Endocrine on April 12th, 2022. See the published version at https://doi.org/10.1007/s12020-022-03048-1. 


\section{Abstract}

The Lynch syndrome (LS) is an autosomal dominant disorder characterized by a strongly increased risk of developing colorectal cancer and several extra-colonic malignancies, such as carcinomas of the endometrium, ovary, ureter, stomach, and small intestine [1]. Lynch syndrome is caused by germline mutations in mismatch repair genes (MMR)[2], mainly in $M L H 1$ and $M S H 2$, rarely in $M S H 6$ and $P M S 2[3,4]$. Tumors usually develop at a relatively young age ( $<50$ years). Some cancers, rare in this syndrome, can be incidentally diagnosed in one of the Lynch syndrome family members. Here we report the case of unusual presentation of papillary thyroid carcinoma in a young woman carrying the $c .545+3 \mathrm{~A}>\mathrm{G}$ mutation (rs267607760)in MLH1gene.

\section{Case History}

A 33-year-old woman was referred to our endocrine unit in 2017 because of the incidental finding of antithyroperoxidase autoantibodies presence.Her family was affected by Lynch Syndrome:the father underwent surgery for colon cancer before 50years of age and later for squamous cell carcinoma of the skin and duodenum cancer, two aunts underwent surgery for colorectal and endometrial cancers before age of 50 and one aunt and her sister underwent surgery for endometrial cancer.For this reason,the family was previously submitted to genetic analysis, which found the presence of the same germinal mutation $c .545+3>G$ of $M L H 1 g e n e$ in our patient and 6 first degree relatives thus confirming the Lynch syndrome diagnosis (Supplementary figure 1).

The patient was euthyroid at the first observation and the ultrasound imaging of the neck showed a hypoechoic nodule $(5 \times 6 \times 11 \mathrm{~mm})$ in the left lobe of the thyroid gland. Due to the presence of the germline MLH1 mutation,we decided to perform a fine needle aspiration biopsy of this nodule, and the cytology identified a thyroid carcinoma (TIR5).

The patient underwent total thyroidectomy and pathology confirmed the presence of a classical variant of papillary thyroid carcinoma, with the thyroid capsule infiltration (T1a, NO, Mx). The genetic analysis of the neoplastic thyroid tissue was performed by targeted next-generation sequencing (NGS) using two custom thyroid cancer-specific multi-gene panels that target single-nucleotide variants/small indels (DNA panel) and gene fusions (RNA panel), as previously described[5,6]. The analysis showed the presence of both BRAF p.V600E and TERT c.-124 C>T (also known as C228T) promoter mutations with an allelic frequency of $10 \%$ and $16 \%$, respectively. Radioiodine ablation ( $1850 \mathrm{MBq})$ after $0.9 \mathrm{mg}$ of rhTSH was performed and wholebody scan (WBS) post- 1311 administration showed only a thyroid bed uptake, without other sites of pathological uptake. Stimulated thyroglobulin $(\mathrm{Tg})$ was $0.6 \mathrm{ng} / \mathrm{mL}$ (cut-off $<0.1 \mathrm{ng} / \mathrm{ml}$ ), Tg autoantibodies $(\mathrm{TgAb})$ were $145 \mathrm{UI} / \mathrm{mL}(0-60 \mathrm{UI} / \mathrm{mL})$.

$\mathrm{Tg}$ is currently $<0.1 \mathrm{ng} / \mathrm{mL}, \mathrm{TgAb}$ are $15 \mathrm{Ul} / \mathrm{mL}$. Ultrasound imaging of the neck is negative for the presence of suspicious lymph nodes. No other neoplasms have been diagnosed during a four-year follow-up.

\section{Discussion}


Lynch syndrome diagnosis is based on the application of Amsterdam criteria, which applies the "3-2-1 Rule", and the Amsterdam second classification, which includes non-colorectal cancers: endometrial, small intestine, ureteral, and kidney cancers [7]. The "3-2-1 Rule" criteria include $\geq 3$ affected family members, one of whom is a first-degree relative of the other two, across at least 2 generations with at least 1 of them presenting with hereditary non polyposis colorectal cancer (HNPCC) before the age of 50 . The familial adenomatous polyposis should be excluded. Lynch syndrome is caused by germline mutations in one of four DNA mismatch repair genes that lead to microsatellite instability and/or loss of mismatch repair protein expression at immunohistochemistry [1, 2]. In 90\% of cases, mutations can be found in $\mathrm{MLH} 1$ or MSH2 genes, while mutations in MSH6 and PMS2 genes are less frequent [1, 2].

The etiology of tumors that are usually rare in the HNPCC tumor spectrum is still controversial. Here, we report the case of a 33-year-old woman with a family history of Lynch syndrome, due to a germline MLH1 gene mutation, who developed a papillary thyroid carcinoma.

Only a few cases of thyroid cancer have been reported in patients with Lynch syndrome, mostly associated with an MSH2 germline mutation (Table 1). Interestingly, Aswath $\mathrm{K}$ et al., described a family with the cooccurrence of familial non-medullary thyroid cancer (FNMTC) and HNPCC. Two out of five relatives affected by PTCs were analyzed and both carried the germline MSH2 p.C707Y variation[8]. Although the clinical significance of the $M S H 2$ variant is uncertain, it may suggest a role in PTC predisposition.

To our knowledge, only one thyroid cancer associated with a germline $M L H 1$ mutation has been previously described in a patient with Lynch syndrome. The patient was a 43-year-old female who developed PTC a few years after the uterine and ovarian adenocarcinomas and colon cancer. Unfortunately, we have no data about the genetic analysis on thyroid cancer tissue[9].

Here, we report a second patient carrying a germline $M L H 1$ mutation. The $M L H 1 \mathrm{c} .545+3 \mathrm{~A}>\mathrm{G}$ variation is known to be pathogenic leading to the skipping of exon 6 . The genetic analysis of the thyroid cancer tissue showed the coexistence of BRAF p.V600E and TERTC228T promoter mutations.Notably, this is the first case in whom papillary thyroid carcinoma has been diagnosed as the first and isolated neoplastic disease in a Lynch syndrome family member. During the 4 years follow-up the patient didn't develop any Lynchassociated cancers.

Genes involved in DNA repair pathways have a pivotal role in preserving genomic integrity upon exposure to genotoxic agents and the impairments in these mechanisms are related to increases in mutation frequency, genomic instability, and finally to cancer susceptibility $[10,11]$.

Although thyroid cancer is not considered as part of Lynch syndrome, several reports have indicated an association between MMR deficiency and thyroid cancer.

Lu Y et al. found a lower expression of MLH1 protein in thyroid cancer tissues, both papillary and follicular cancers, compared with normal tissues [12]. Moreover, $M L H 1$ germline and somatic mutations have been described in PTCs $[10,12]$. 
The defective DNA repair system in a condition of excessive oxidative stress that promotes the DNA oxidation and subsequent lesions may have an important role in the PTC tumorigenesis $[9,13]$. It is therefore reasonable to suppose that MMR impairment, including that induced by $M L H 1$ mutations, may increase the chance of somatic genetic alterations. Our patient follows this hypothesis being a carrier of two somatic driver mutations in the PTC tissue. Moreover, in all analyzed PTC tissues of patients with Lynch Syndrome, including our patient, it has been found a somatic BRAF p.V600E mutation (Table 1). Interestingly, the association between the aberrant $M L H 1$ methylation and expression and the presence of the BRAF p.V600E mutation has been described in thyroid cancer cell lines and PTC tissues [10].

In conclusion, although we cannot exclude an incidental occurrence of PTC in Lynch syndrome patients, our study underlines the need to follow-up LS patients for the development of rare associated cancers, including thyroid cancers.

\section{Declarations}

\section{Compliance with ethical standard}

\section{Conflict of interest}

The authors declare that they have no conflict of interest

\section{Informed consent}

Patient gave her informed consent.

\section{References}

1. A. Umar et al., "Revised Bethesda Guidelines for hereditary nonpolyposis colorectal cancer (Lynch syndrome) and microsatellite instability," J. Natl. Cancer Inst., 2004

2. F.M. Giardiello et al., "Guidelines on genetic evaluation and management of lynch syndrome: A consensus statement by the us multi-society task force on colorectal cancer," Dis. Colon Rectum, 2014

3. R.P. Stulp, J.C. Herkert, A. Karrenbeld, B. Mol, Y.J. Vos, R.H. Sijmons, "Thyroid cancer in a patient with a germline MSH2 mutation. Case report and review of the Lynch syndrome expanding tumour spectrum," Hereditary Cancer in Clinical Practice. 2008

4. R.R. Broaddus, P.M. Lynch, K.H. Lu, R. Luthra, S.J. Michelson, "Unusual tumors associated with the hereditary nonpolyposis colorectal cancer syndrome," Mod. Pathol., 2004

5. M. Sponziello et al., "Performance of a dual-component molecular assay in cytologically indeterminate thyroid nodules," Endocrine, 2020

6. A. Verrienti et al., "Analytical validation of a novel targeted next-generation sequencing assay for mutation detection in thyroid nodule aspirates and tissue," Endocrine, 2020

7. L.R. Lipton et al., "Refining the Amsterdam criteria and Bethesda guidelines: Testing algorithms for the prediction of mismatch repair mutation status in the familial cancer clinic," J. Clin. Oncol., 2004 
8. K. Aswath et al., "Co-Occurrence of Familial Non-Medullary Thyroid Cancer (FNMTC) and Hereditary Non-Polyposis Colorectal Cancer (HNPCC) Associated Tumors-A Cohort Study," Front. Endocrinol. (Lausanne)., 2021

9. M.R. Pelizzo et al., "Papillary thyroid carcinoma (PTC) in Lynch syndrome: Report of two cases and discussion on Lynch syndrome behaviour and genetics," Biomed. Pharmacother., 2015

10. B.S. Lutz et al., "Imbalance in DNA repair machinery is associated with BRAF V600E mutation and tumor aggressiveness in papillary thyroid carcinoma," Mol. Cell. Endocrinol., 2018

11. C. Mio, A. Verrienti, V. Pecce, M. Sponziello, G. Damante, “Rare germline variants in DNA repair-related genes are accountable for papillary thyroid cancer susceptibility," Endocrine, 2021

12. Y. Lu, B. Jiang, Y. Yuan, J. Fei, J. Wang, "MutL homolog 1 expression in thyroid carcinoma and its clinical significance," J. Cancer Res. Ther., 2016

13. S. Fujita, K. Masago, "Alteration of DNA mismatch repair capacity underlying the co-occurrence of nonsmall-cell lung cancer and nonmedullary thyroid cancer," Sci. Rep., 2021

14. M. Javid et al., "DNA Mismatch Repair Deficiency Promotes Genomic Instability in a Subset of Papillary Thyroid Cancers," World J. Surg., 2018

15. A.L. Feng, A. Le, D.N. Johnson, M.A. Varvares, “Multiple simultaneous head and neck cancers in Lynch syndrome: Case report and literature review," Laryngoscope, 2018

16. M. Ponz de, Leon et al., "Risk of colorectal polyps and of malignancies in asymptomatic carriers of mutations in the main DNA mismatch repair genes," Scand. J. Gastroenterol., 2018

17. J.M. Johnson et al., "Molecular Profiling of Synchronous Colon Cancers and Anaplastic Thyroid Cancer in a Patient with Lynch Syndrome," J. Gastrointest. Cancer, 2018

\section{Tables}

Table 1: Clinical and genetic features of Lynch-syndrome patients who developed thyroid cancers 


\begin{tabular}{|c|c|c|c|c|c|c|}
\hline $\begin{array}{l}\text { \# Lynch } \\
\text { syndrome } \\
\text { families }\end{array}$ & $\begin{array}{l}\text { Germline } \\
\text { mutations in MMR } \\
\text { genes }\end{array}$ & Gender & $\begin{array}{l}\text { Tumor type (age } \\
\text { at diagnosis) }\end{array}$ & $\begin{array}{l}\text { Thyroid } \\
\text { cancer } \\
\text { TNM }\end{array}$ & $\begin{array}{l}\text { Somatic } \\
\text { mutations } \\
\text { in thyroid } \\
\text { cancer } \\
\text { tissue }\end{array}$ & References \\
\hline \multirow[t]{4}{*}{$1^{\wedge}$} & \multirow[t]{4}{*}{ MSH2 p.C707Y } & \multirow[t]{3}{*}{$\mathrm{F}$} & $\begin{array}{l}\text { Colon polyps } \\
(20)\end{array}$ & \multirow[t]{3}{*}{ T4N1bM0 } & \multirow[t]{3}{*}{$\begin{array}{l}\text { BRAF } \\
\text { p.V600E }\end{array}$} & \multirow[t]{4}{*}{ [8] } \\
\hline & & & $\begin{array}{l}\text { Papillary thyroid } \\
\text { carcinoma (53) }\end{array}$ & & & \\
\hline & & & Melanoma (63) & & & \\
\hline & & $F$ & $\begin{array}{l}\text { Papillary thyroid } \\
\text { carcinoma (33) }\end{array}$ & T1aNOMO & $\begin{array}{l}\text { BRAF } \\
\text { p.V600E }\end{array}$ & \\
\hline 2 & MSH2 p.Q824X & $\mathrm{F}$ & $\begin{array}{l}\text { Anaplastic } \\
\text { thyroid cancer } \\
\text { (39) }\end{array}$ & na & na & [4] \\
\hline \multirow[t]{2}{*}{3} & \multirow[t]{2}{*}{$\begin{array}{l}\text { MSH2 } \\
\text { c. } 1704 \_1705 \text { delAG }\end{array}$} & \multirow[t]{2}{*}{$\mathrm{F}$} & $\begin{array}{l}\text { Colorectal } \\
\text { adenoma (44) }\end{array}$ & \multirow[t]{2}{*}{ na } & \multirow[t]{2}{*}{ na } & \multirow[t]{2}{*}{ [3] } \\
\hline & & & $\begin{array}{l}\text { Anaplastic } \\
\text { thyroid cancer } \\
\text { (44) }\end{array}$ & & & \\
\hline \multirow[t]{2}{*}{4} & \multirow[t]{2}{*}{$\begin{array}{l}\text { MSH2 } \\
\text { c.906_907insT }\end{array}$} & M & $\begin{array}{l}\text { Colon cancer } \\
(21)\end{array}$ & \multirow[t]{2}{*}{ pT4pN1b } & \multirow[t]{2}{*}{ na } & \multirow[t]{2}{*}{ [9] } \\
\hline & & & $\begin{array}{l}\text { Papillary thyroid } \\
\text { carcinoma (34) }\end{array}$ & & & \\
\hline \multirow[t]{4}{*}{5} & \multirow[t]{4}{*}{ MSH2 na } & \multirow[t]{4}{*}{$M$} & $\begin{array}{l}\text { Colon } \\
\text { adenocarcinoma } \\
\text { (33) }\end{array}$ & \multirow[t]{4}{*}{ na } & \multirow[t]{4}{*}{$\begin{array}{l}\text { BRAF } \\
\text { p.V600E }\end{array}$} & \multirow[t]{4}{*}{ [15] } \\
\hline & & & $\begin{array}{l}\text { Salivary gland } \\
\text { adenocarcinoma } \\
\text { (44) }\end{array}$ & & & \\
\hline & & & $\begin{array}{l}\text { Papillary thyroid } \\
\text { carcinoma (44) }\end{array}$ & & & \\
\hline & & & $\begin{array}{l}\text { Parotid acinic } \\
\text { cell carcinoma } \\
(44)\end{array}$ & & & \\
\hline
\end{tabular}

\begin{tabular}{|c|c|c|c|c|c|}
\hline 9 & MSH2 c. 2646 delA & $F$ & $\begin{array}{l}\text { thyroid cancer§ } \\
\text { (37) }\end{array}$ & na & na \\
\hline \multirow[t]{2}{*}{6} & \multirow[t]{2}{*}{$\begin{array}{l}\text { MSH6 } \\
\text { p.G1105fs*3 }\end{array}$} & \multirow[t]{2}{*}{$F$} & $\begin{array}{l}\text { Colorectal } \\
\text { adenocarcinoma } \\
(54)\end{array}$ & \multirow[t]{2}{*}{ pT4bN1b } & \multirow{2}{*}{$\begin{array}{l}\text { AKT1 } \\
\text { p.E17K; } \\
\text { ARID1A } \\
\text { p.I106fs*4 } \\
\text { ATM } \\
\text { p.R3008H; } \\
\text { PI3KCA } \\
\text { p.R38C; }\end{array}$} \\
\hline & & & $\begin{array}{l}\text { Anaplastic } \\
\text { thyroid cancer } \\
\text { (54) }\end{array}$ & & \\
\hline
\end{tabular}




\begin{tabular}{|c|c|c|c|c|c|c|}
\hline & & & & & $\begin{array}{l}\text { PTEN } \\
\text { p.R335*; } \\
\text { RB1 c.265- } \\
\text { 1G > T; } \\
\text { TP53 } \\
\text { p.R196* }\end{array}$ & \\
\hline \multirow[t]{4}{*}{7} & \multirow[t]{4}{*}{ MLH1 c. $1858 G>T$} & \multirow[t]{4}{*}{$\mathrm{F}$} & $\begin{array}{l}\text { Uterine } \\
\text { adenocarcinoma } \\
\text { (43) }\end{array}$ & \multirow[t]{4}{*}{ pT1aN1a } & \multirow[t]{4}{*}{ na } & \multirow[t]{4}{*}{ [9] } \\
\hline & & & $\begin{array}{l}\text { Ovarian } \\
\text { adenocarcinoma } \\
\text { (43) }\end{array}$ & & & \\
\hline & & & $\begin{array}{l}\text { Colon cancer } \\
(45)\end{array}$ & & & \\
\hline & & & $\begin{array}{l}\text { Papillary thyroid } \\
\text { carcinoma (47) }\end{array}$ & & & \\
\hline 8 & $\begin{array}{l}\text { MLH1 } \\
\text { c. } 545+3 A>G\end{array}$ & $\mathrm{~F}$ & $\begin{array}{l}\text { Papillary thyroid } \\
\text { carcinoma (36) }\end{array}$ & T1aN0Mx & $\begin{array}{l}\text { BRAF } \\
\text { p.V600E + } \\
\text { TERT } \\
\text { C228T }\end{array}$ & this paper \\
\hline
\end{tabular}

na= not available

${ }^{\wedge}$ Family with HNPCC and FNMTC

$\S$ Not specified

\section{Supplementary Files}

This is a list of supplementary files associated with this preprint. Click to download.

- Figure12.pptx 